\title{
LONGIVITAS DAN RECOVERY RATE PASCA THAWING SEMEN BEKU SAPI FRESIAN HOLSTEIN MENGGUNAKAN BAHAN PENGENCER YANG BERBEDA
}

\author{
Arifiantini, I., T. L. Yusuf, dan Graha $\mathrm{N}^{1}$
}

\section{INTISARI}

Penelitian ini bertujuan untuk membandingkan pengencer semen yang terbaik antara tris raffinosa kuning telur endapan resep dari salah satu Balai Inseminasi Buatan (TS), tris fruktosa kuning telur buatan lokal FKH IPB (TF), dan pengencer paten AndroMed (Minitub Germany) yang menggunakan lesitin dari kacang kedelai $(\mathrm{KK})$ terhadap longivitas dan pemulihan spermatozoa setelah pembekuan (recovery rate). Semen dikoleksi dari tiga ekor sapi Friesian holstein (FH) jantan sebanyak 18 ejakulat menggunakan vagina buatan. Ejakulat tersebut dievaluasi dan diencerkan dengan pengencer TS, TF, dan KK. Kemudian semen dikemas menggunakan straw minitub dengan konsentrasi $25.10^{6}$ per $0,3 \mathrm{mil}$ spermatozoa. Straw diekuilibrasi pada suhu $4^{\circ} \mathrm{C}$, kemudian dibekukan dalam uap $\mathrm{N}_{2}$ cair selama 15 menit, dan disimpan dalam kontainer nitrogen cair $\left(-196^{\circ} \mathrm{C}\right)$. Setelah 24 jam penyimpanan, semen diencerkan pada suhu $37^{\circ} \mathrm{C}$ selama 30 detik, kemudian diinkubasi dalam water bath $\left(37^{\circ} \mathrm{C}\right)$ selama 9 jam untuk mengevaluasi longivitas dan recovery rate (RR). Variabel kualitas yang diamati adalah sperma motil pasca thawing, Longivitas spermatozoa pasca thawing pada bahan pengencer $\mathrm{KK}$ ( $6 \mathrm{jam}$ ) sangat berbeda nyata lebih lama dibandingkan kedua pengencer yang lain $(\mathrm{P}<0,01)$, sedangkan antara pengencer TF dan TS memiliki longivitas yang tidak berbeda nyata $(\mathrm{P}>0,05)$. Recovery rate $(\mathrm{RR})$ spermatozoa pada pengencer $\mathrm{KK}(69,56 \%)$ lebih tinggi daripada pengencer TS $(63.48 \%)$ dan TF $(59,40 \%)$. Dari penelitian yang telah dilakukan dapat disimpulkan bahwa pengencer KK mempunyai longivitas dan RR terbaik dibandingkan pengencer TS dan TF pada semen beku sapi FH.

(Kata kunci ; Longivitas, Recovery rate, Bahan pengencer semen, Thawing).

Buletin Peternakan 29 (2): $53-61,2005$

${ }^{1}$ Fakultas Kedokteran Hewan, Institut Pertanian Bogor, Bogor. 


\title{
LONGEVITY AND RECOVERY RATE OF FREEZE FRESIAN HOLSTEIN BULL SEMEN ON DIFFERENT EXTENDER
}

\begin{abstract}
This experiment was designed to make comparison between three different extenders among tris raffinose egg yolk (TS), tris fructose egg yolk (TF) and commercial extender AndroMed (minitub, Germany) based on soya lechitin (KK) for frozen bull semen on the longevity and recovery rate (RR). Semen was collected using an artificial vagina from 18 ejaculates of 3 Friesian Holstein (FH) bulls. Each ejaculate was divided into 3 parts and diluted in KK, TS and TF. Extended semen was placed into straw minitub with the concentration of 25 million cells $/ 0.3 \mathrm{ml}$, equilibrated, frozen and stored in liquid nitrogen $\left(\mathrm{N}_{2}\right)$ at $-196^{\circ} \mathrm{C}$. Semen was thawed after 24 hours storage at $37^{\circ} \mathrm{C}$ for 30 seconds and placed into water bath at $37^{\circ} \mathrm{C}$ for 9 hours to evaluate sperm longevity and recovery rate. Sperm motility post thawed estimated regularly to measured longevity and recovery rate (RR). Sperm longevity of the KK extender ( 6 hours) was highly longer $(\mathrm{P}<0.01)$ than other extender. There was no significant different between TS and TF extender $(\mathrm{P}>0.05)$. Recovery rate of post thawed semen in extender KK $(69.56 \%)$ highly significantly better when compared to TS $(63.48 \%)$ and TF $(59.40 \%)$. The conclusion was that KK extender caused longevity and RR better than the two other extenders.
\end{abstract}

(Key word: Longevity, Recovery rate, Extender, Thawing).

\section{Pendahuluan}

Peningkatan konsumsi daging sapi per kapita penduduk Indonesia cenderung meningkat seiring bertambahnya jumlah penduduk. Konsumsi daging per kapita tahun 2006 diperkirakan 1,633 kg/tahun (Tanari, 2001). Sementara itu, pada sisi lain, pertumbuhan populasi temak secara nasional tidak mampu mengimbangi peningkatan permintaan sehingga berakibat adanya kelebihan permintaan. Dalam rangka menanggulangi masalah tersebut, ditempuh berbagai upaya. Salah satu upaya yang ditempuh untuk meningkatkan jumlah populasi ternak dan perbaikan mutu genetik adalah dengan menerapkan inseminasi buatan.

Inseminasi buatan (IB) adalah pemasukan semen ke dalam saluran kelamin betina dengan menggunakan alat-alat buatan manusia. Adanya penerapan IB akan meningkatkan nilai guna induk jantan. Dengan menggunakan teknik IB satu pejantan unggul dapat mengawini ribuan betina (Campbell et al., 2003) tetapi jika kawin secara alami pejantan hanya mampu mengawini 30-50 betina. Selain itu, IB akan memperbaiki mutu genetik 3-4 kali lebih cepat daripada kawin alam.

Salah satu faktor yang menentukan keberhasilan IB adalah kualitas semen yang digunakan (Webb, 2004). Untuk mempertahankan daya hidup spermatozoa in vitro dan mengoptimalkan semen pada saat IB, dibutuhkan bahan pengencer semen yang baik. Seperti diketahui bahwa jenis pengencer semen sangat bervariasi dan masing-masing memiliki keistimewaan (Paulenz et al,, 2002). Dengan adanya perbedaan jenis bahan pengencer, maka pertanyaan yang selalu muncul adalah pengencer semen manakah yang paling baik. Penelitian ini bertujuan untuk mencari pengencer semen terbaik agar semen beku yang dihasilkan semakin berkualitas.

\section{Materi dan Metode}

\section{Tempat dan waktu penelitian}

Penelitian ini dilaksanakan di Laboratorium Unit Rehabilitasi dan Reproduksi (URR) Departemen Reproduksi dan Kebidanan Fakultas Kedokteran Hewan (FKH) Institut 
Pertanian Bogor (IPB) pada bulan Februari sampai September 2004.

\section{Persiapan bahan pengencer}

Pembuatan pengencer TS. Pengencer TS dibuat tiga hari sebelum penampungan dengan komposisi seperti yang terdapat pada Tabel 1. Campuran disimpan dalam gelas ukur pada temperatur $4^{\circ} \mathrm{C}$ dan pada hari penampungan diambil supernatannya saja.

Pembuatan pengencer KK. Pengencer KK dibuat pada hari penampungan. Cara pembuatannya adalah dengan mencampurkan stock pengencer komersial yang mengandung kacang kedelai dengan aquabidest 1 banding 4 lalu dihomogenkan.

Pembuatan Pengencer TF. Pengencer TF dibuat sebelum melakukan penampungan. Cara pembuatan pengencer ini dengan mencampurkan semua bahan kimia yang terdapat pada Tabel 1 kemudian dihomogenkan.

Penampungan semen. Penelitian ini menggunakan 18 ejakulat dari tiga ekor sapi FH yang telah dewasa kelamin dengan bobot badan $800-900 \mathrm{~kg}$. Pakan yang diberikan berupa hijauan rumput sebanyak $10 \%$ dan konsentrat sebanyak $1 \%$ dari bobot badan. Air minum diberikan secara ad libitum. Semen ditampung menggunakan vagina buatan dua kali seminggu pada pagi hari. Semen yang dikoleksi dibawa ke laboratorium untuk dievaluasi.

\section{Evaluasi semen}

Semen dievaluasi secara makroskopik dan mikroskopik. Pemeriksaan makroskopik antara lain: volume semen yang dilakukan dengan melihat skala pada tabung penampung, derajat keasaman $(\mathrm{pH})$ yang dilihat dengan menggunakan $p H$ indicator paper (Merck skala 6,4-10), konsistensi, dan warna semen. Pemeriksaan mikroskopik meliputi: gerakan massa, persentase sperma motil dengan menambahkan $\mathrm{NaCl}$ fisiologis dan dinilai secara estimasi dari lima lapang pandang, dan persentase sperma hidup dan abnormal yang dilakukan menggunakan preparat differensial dengan pewamaan eosin negrosin. Persentase sperma hidup dan abnormal dihitung sejumlah 200 sel. Konsentrasi sperma dihitung menggunakan kotak hitung Neubauer.

\section{Pengenceran, pengemasan dan pembekuan semen}

Semen yang mempunyai kualitas yang baik ( $>70 \%$ sperma motil) dibagi menjadi tiga bagian dengan volume yang sama dan diencerkan dengan metode satu tahap menggunakan pengencer TS, TF dan KK.

Tabel 1. Komposisi bahan pengencer yang digunakan (Extender composition)

\begin{tabular}{|c|c|c|c|}
\hline Komposisi bahan (Compotition of ingredient) & TS & TF & KK \\
\hline Tris aminomethan $(\mathrm{g})^{1)}$ & 1,6 & 3,87 & - \\
\hline Asam sitrat (Citric acid) $(\mathrm{g})^{1)}$ & 0,9 & 2,17 & - \\
\hline Laktosa (Lactose) $(\mathrm{g})^{1)}$ & 1,4 & - & - \\
\hline $\begin{array}{l}\text { Raffinosa (Raffinose) }(\mathrm{g})^{2)} \\
\text { Fruktosa (Fructose) }\end{array}$ & 2,5 & - & - \\
\hline $\begin{array}{l}\text { Fruktosa (Fructose) }(\mathrm{g})^{1 /} \\
\text { Kuning telur }\left(\text { Egg volk) }(\mathrm{ml})^{3)}\right.\end{array}$ & - & 1,56 & - \\
\hline $\begin{array}{l}\text { Kuning telur (Egg yolk) }(\mathrm{ml})^{3)} \\
\text { Penicillin (IU) })^{4}\end{array}$ & 20 & 20 & - \\
\hline & 100.000 & 100.000 & - \\
\hline Gliserol (Glycerol) & 100 & 100 & - \\
\hline Pengencer Komersial (Commercial extender) & 6 & 6,4 & - \\
\hline Aquabidest (ml) ad & 100 & 100 & $\begin{array}{c}20 \\
100\end{array}$ \\
\hline
\end{tabular}


Pengenceran dilakukan dengan penghitungan sebagai berikut :

Volume Total $=\frac{\mathrm{a} \times \mathrm{b} \times \mathrm{c}}{\mathrm{d}}$
a: Volume semen
b : Konsentrasi spermatozoa (ml)
c : Persentase sperma motil
d: Volume straw minitub

Setelah itu semen dikemas dalam straw minitub dengan konsentrasi 25 juta sel spermatozoa $/ 0,3 \mathrm{ml}$, diekuilibrasi selama 4 jam pada suhu $4^{\circ} \mathrm{C}$, dibekukan di atas uap $\mathrm{N}_{2}$ cair selama 10-15 menit, dan disimpan dalam kontainer yang berisi $\mathrm{N}_{2} \operatorname{cair}\left(-196^{\circ} \mathrm{C}\right)$.

\section{Thawing semen beku}

Thawing semen beku dilakukan 24 jam setelah penyimpanan, pada suhu $37^{\circ} \mathrm{C}$ selama 30 detik. Setelah itu, semen dimasukkan ke dalam tabung dan diinkubasi dalam water bath $\left(37^{\circ} \mathrm{C}\right)$. Sperma diamati motilitasnya menggunakan mikroskop cahaya dengan pembesaran $400 \mathrm{X}$. Persentase sperma motil dihitung dengan skala $0-5 \%$ dimulai dari $0 \%$ hingga $100 \%$. Motilitas dihitung setiap jam dari jam ke- 0 sampai jam ke9 hingga motilitas mencapai $0 \%$ untuk mengetahui longivitas sperma. Sedangkan untuk mendapatkan nilai RR (Garner dan Hafez, 2000) dilakukan penghitungan sebagai berikut:

$$
\mathrm{RR}=\frac{\mathrm{a}}{\mathrm{b}} \times 100 \%
$$

a : Persentase sperma motil pasca thawing

$b$ : Persentase sperma motil pada semen segar

\begin{abstract}
Analisis data
Percobaan ini dirancang menggunakan rancangan acak lengkap (RAL) pola searah. Penelitian ini dilakukan dengan ulangan sebanyak 6 kali (18 ejakulat). Data yang diperoleh dianalisis menggunakan analisis variansi dengan program minitab 13.
\end{abstract}

\section{Hasil dan Pembahasan}

\section{Karakteristik semen segar}

Hasil penelitian dari 18 ejakulat sapi FH masih berada pada kisaran normal dan dikategorikan semen yang berkualitas cukup baik (Tabel 2).

Dari hasil pemeriksaan makroskopis semen segar diperoleh volume semen rata-rata $6,60 \mathrm{ml}$, dengan warna kuning krem, konsistensi sedang, dan pH 6,58. Pemeriksaan mikroskopis menunjukkan gerakan massa spermatozoa berkisar antara ++ sampai +++, konsentrasi spermatozoa 991,32 juta $\mathrm{sel} / \mathrm{ml}$. Persentase sperma motil yang diperoleh sebesar $72,63 \%$ dan persentase sperma hidup sebesar $85,16 \%$ serta sperma abnormal dengan 5,90

Tabel 2. Karakteristik semen segar sapi FH (Characteristic of FH fresh semen)

\begin{tabular}{lc}
\hline \multicolumn{1}{c}{ Karakteristik semen (Characteristicts of semen) } & Nilai rataan (Mean) \\
\hline Volume (mi) & $6,60 \pm 2,12$ \\
Warna (Colour) & kuning krem (Yellowiss cream) \\
Konsistensi (Consistency) & Sedang (Medium) \\
pH $(p H)$ & 6,58 \\
Gerakan massa (Mass mobility) & $+1+1+$ \\
Konsentrasi sperma (juta $^{-m l}$ ) (Sperm concentration) & $991,32 \pm 14,14$ \\
Motilitas sperma (Sperm motility) $(\%)$ & 72,63 \\
Sperma hidup (Life sperm) $(\%)$ & $86,16 \pm 2,78$ \\
Abnormalitas sperma (Sperm abnormality) (\%) & $5,90 \pm 1,60$ \\
\hline
\end{tabular}




\section{Pemeriksaan semen beku pasca thawing} Recovery rate semen beku pasca thawing. Recovery rate ( $R R$ ) adalah kemampuan pemulihan spermatozoa setelah pembekuan dengan membandingkan persentase sperma motil pada semen segar dengan pasca thawing (Gamer dan Hafez, 2000). Hasil penelitian menunjukkan RR semen beku pada masing-masing pengencer seperti pada Tabel 3 menunjukkan bahwa semen beku pasca thawing pada pengencer KK memiliki RR sangat nyata $(\mathrm{P}<0.01)$ lebih tinggi $(69.56 \%)$ dibanding pengencer TS $(63.48 \%)$ dan TF $(59.40 \%)$.
Sedangkan pengencer TS dan TF memiliki RR semen beku pasca thawing yang tidak berbeda nyata $(\mathrm{P}>0,05)$.

Longivitas semen beku pasca thawing. Longivitas atau daya tahan hidup adalah kemampuan spermatozoa bertahan pada temperatur tertentu. Pada penelitian ini semen beku pasca thawing akan disimpan pada suhu $37^{\circ} \mathrm{C}$ dan diamati motilitasnya tiap jam. Perbandingan persentase sperma motil dengan masing-masing pengencer dari jam ke-0 sampai jam ke-9 pasca thawing dapat dilihat pada Tabel4.

Tabel 3. Recovery rate semen beku sapi FH pasca thawing

(Recovery rate after thawing $F H$ frozen semen)

\begin{tabular}{cccc}
\hline Pengencer (Extender) & \multicolumn{2}{c}{ Motilitas sperma (Sperm motility) (\%) } & Recovery rate (\%) \\
\cline { 2 - 3 } & $\begin{array}{c}\text { Semen segar } \\
\text { (Fresh semen) }\end{array}$ & $\begin{array}{c}\text { Pasca thawing } \\
\text { (Post thowing) }\end{array}$ & \\
\hline KK & 72,63 & $50,20 \pm 7,07^{\mathrm{a}}$ & $69,56 \pm 11,32^{\mathrm{a}}$ \\
TS & & $46,04 \pm 3,54^{\mathrm{b}}$ & $63,48 \pm 9,25^{\mathrm{b}}$ \\
TF & & $43,02 \pm 7,68^{\mathrm{b}}$ & $59,40 \pm 11,24^{\mathrm{b}}$ \\
\hline
\end{tabular}

$\$, 6$ Superskrip yang berbeda pada kolom yang sama menunjukkan perbedaan yang sangat nyata $(\mathrm{P}<0,01)$. (Different superscript at the same coloumn indicating significant differences $(P<0,0 I)$ )

KK(Pengencer yang mengandung kacang kedelai) (Soybean containing extender): TS (Tris Raffinose); TF (Tris Fructose).

Tabel 4. Sperma motil (\%) pasca thawing pada tiap jam pengamatan dengan tiga macam bahan pengencer (After thawing motility on every hour evaluation using three different extender)

\begin{tabular}{cccc}
\hline Jam pengamatan & \multicolumn{3}{c}{ Motilitas sperma (Sperm motility) (\%) } \\
\cline { 2 - 4 } (Observation time) & KK & TS & TF \\
\hline 0 & $50,20 \pm 7,07^{\mathrm{a}}$ & $46,04 \pm 3,54^{\mathrm{b}}$ & $43,02 \pm 7,68^{\mathrm{b}}$ \\
1 & $43,49 \pm 7,07^{\mathrm{a}}$ & $38,21 \pm 3,54^{\mathrm{b}}$ & $34,72 \pm 7,07^{\mathrm{b}}$ \\
2 & $34,34 \pm 7,07^{\mathrm{a}}$ & $29,34 \pm 0^{\mathrm{b}}$ & $25,75 \pm 14,14^{\mathrm{b}}$ \\
3 & $26,51 \pm 14,14^{\mathrm{a}}$ & $17,45 \pm 10,61^{\mathrm{b}}$ & $16,51 \pm 14,14^{\mathrm{b}}$ \\
4 & $20,81 \pm 17,68^{\mathrm{a}}$ & $10,09 \pm 7,07^{\mathrm{b}}$ & $10,61 \pm 8,49^{\mathrm{b}}$ \\
5 & $17,68 \pm 15,57^{\mathrm{a}}$ & $5,47 \pm 3,54^{\mathrm{b}}$ & $3,53 \pm 3,11^{\mathrm{b}}$ \\
6 & $10,57 \pm 7,07^{\mathrm{a}}$ & $2,74 \pm 0^{\mathrm{b}}$ & $1,23 \pm 0^{\mathrm{b}}$ \\
7 & $6,89 \pm 3,54^{\mathrm{a}}$ & $1,42 \pm 0^{\mathrm{b}}$ & $0,75 \pm 0^{\mathrm{b}}$ \\
8 & $3,68 \pm 3,54^{\mathrm{a}}$ & $0,47 \pm 0^{\mathrm{b}}$ & $0,09 \pm 0^{\mathrm{b}}$ \\
9 & 0 & 0 & 0
\end{tabular}

\footnotetext{
${ }^{2, b}$ Superskrip yang berbeda pada baris yang sama menunjukkan perbedaan yang sangat nyata $(\mathrm{P}<0.01)$ (Different superscript at the same raw indicating significant differences $(P<0,01)$ )

KK (Pengencer yang mengandung kacang kedelai) (Soybean containing extender); TS (Tris Raffinose); TF (Tris Fructose).
} 
Tabel 5. Longivitas semen beku sapi FH pasca thawing hingga motilitas $10 \%$ (Longevity of FH bull frozen semen after thawing until $10 \%$ motility)

\begin{tabular}{cc}
\hline Jenis pengencer (Kind of extender) & Longivitas (jam) (Longitivity (hours)) \\
\hline KK & $6^{\mathrm{a}}$ \\
TS & $4^{\mathrm{b}}$ \\
TF & $4^{\mathrm{b}}$ \\
\hline
\end{tabular}

$\mathrm{a}, \mathrm{b}$ Superskrip yang berbeda pada kolom yang sama menunjukkan perbedaan yang sangat nyata $(\mathrm{P}<0.01)$ (Different superscript at the same coloumn indicating significant differences $(P<0,01)$ ) KK (Pengencer yang mengandung kacang kedelai) (Soybean containing extender); TS (Tris Raffinose); TF (Tris Fructose).

Berdasarkan hasil pengamatan pasca thawing jam ke-0, pengencer KK memiliki persentase sperma motil $(50,20 \%)$ yang sangat nyata lebih tinggi $(\mathrm{P}<0,01)$ dibandingkan pengencer TS $(46,04 \%)$ dan TF $(43,02 \%)$. Sedangkan persentase sperma motil tiap jam pengamatan pada pengencer TS dan TF tidak menunjukkan adanya perbedaan yang nyata $(\mathrm{P}>0,05)$.

Longivitas sperma pasca thawing pada pengencer KK menunjukkan perbedaan yang sangat nyata $(\mathrm{P}<0,01)$ lebih lama $(6$ jam $)$ dibanding pengencer yang lain (4 jam). Sedangkan longivitas sperma pasca thawing pada pengencer TS dan TF tidak berbeda nyata $(\mathrm{P}>0,05)$.

\section{Semen segar}

Dari hasil yang telah dikemukakan terlihat bahwa semen segar sapi FH yang digunakan dalam penelitian ini, memiliki kualitas yang cukup baik. Hal ini terlihat dari pemeriksaan makroskopis semen segar yang didapatkan masih dalam kisaran normal. Menurut Garner dan Hafez (2000), volume semen sapi setiap satu kali ejakulasi berkisar antara $5-8 \mathrm{ml}$. Volume yang diperoleh sedikit berbeda. Hal ini bisa saja terjadi karena perbedaan individu ternak, umur, musim, nutrisi, bangsa ternak, frekuensi ejakulat, libido, dan kondisi ternak itu sendiri.

Warna semen yang diperoleh selama penelitian adalah kuning krem. Menurut Bearden dan Fuquay (1997), biasanya ejakulat normal semen sapi berwarna putih krem. Semen sapi bisa saja berwarna kuning disebabkan banyaknya pigmen riboflavin dan pigmen ini tidak mempengaruhi kesuburan spermatozoa. Derajat keasaman $(\mathrm{pH})$ semen yang diperoleh selama penelitian masih berada pada kisaran $\mathrm{pH}$ semen sapi menurut Garner dan Hafez (2000), yaitu $6,4-7,8$. Derajat keasaman memegang peranan yang penting karena mempengaruhi viabilitas spermatozoa. Menurut Holm dan Wishart (1998), penurunan $\mathrm{pH}$ internal spermatozoa akan mempengaruhi pengaturan fungsi spermatozoa mamalia dan non mamalia seperti reaksi akrosom dan motilitas.

Pada pemeriksaan secara mikroskopis semen segar selama penelitian, diperoleh gerakan massa spermatozoa berkisar antara + sampai ++ ditandai dengan awan hitam yang tidak begitu gelap tebal dengan gerakan yang cepat berpindah. Nilai yang diperoleh ini, menurut Partodihardjo (1987), dikategorikan dalam semen yang berkualitas baik, artinya spermatozoa tersebut cukup aktif.

Rataan konsentrasi spermatozoa yang diperoleh juga masih berada dalam kisaran nilai yang dikemukakan oleh Campbell et al. (2003), yang menyatakan bahwa konsentrasi spermatozoa pada sapi jantan dewasa berkisar antara 800-1.200 juta/ml semen. Begitu juga yang dikemukakan oleh Garner dan Hafez (2000), bahwa konsentrasi spermatozoa/ml semen sekitar 800-2.000 juta. Tingginya konsentrasi spermatozoa tampak pada warna semen tersebut (Rouge, 2003). Jumlah spermatozoa per unit volume penting untuk mengetahui jumlah bahan pengencer yang 
ditambahkan dan berapa banyak jumlah betina yang dapat diinseminasi (Campbell et al,, 2003).

Persentase sperma motil yang diperoleh selama penelitian juga merupakan nilai yang masih berada dalam kisaran normal menurut Gamer dan Hafez (2000), yaitu antara $40-75 \%$. Campbell et al. (2003), menyatakan bahwa spermatozoa dengan motilitas yang sangat baik berkisar antara $70-80 \%$. Motilitas merupakan uji kualitas yang penting karena fertilitas erat kaitannya dengan sperma motil yang diinseminasikan. Motilitas spermatozoa akan menurun jika terpapar oleh cahaya tetapi akan meningkat di dalam cairan uterus. Motilitas merupakan faktor yang sangat menentukan bagi spermatozoa untuk melewati serviks, bahkan motilitas yang progresif membantu spermatozoa untuk dapat menembus kumulus ooforus dan zona pelucida ovum sehingga fertilisasi dapat terjadi (Garner dan Hafez, 2000).

Rataan persentase sperma hidup yang diperoleh selama penelitian adalah 83,38 $88,94 \%$. Persentase sperma hidup lebih tinggi daripada persentase sperma motil (Bearden dan Fuquay 1997) karena sperma yang hidup belum tentu motil, tetapi sejumlah sperma yang tidak motil terkadang masih hidup (Campbell et al., 2003). Sperma yang mati mengurangi konsentrasi sperma yang fertil, juga toksik bagi sperma lain yang masih hidup.

Jumlah sperma abnormal yang diperoleh juga masih berada dalam kisaran nilai yang dikemukakan oleh Campbell et al. (2003) yang menyatakan bahwa semen yang berkualitas tinggi mengandung maksimal 5-15\% sperma abnormal. Menurut Bearden dan Fuquay (1997), semen biasanya mengandung $5 \%$ spermatozoa yang abnormal, fertilitas tidak akan terganggu sampai tingkat abnormal $20-25 \%$. Sperma yang abnormal tidak menunjukkan motilitas yang progresif. Sperma abnormal biasanya disebabkan oleh kejutan dingin atau panas, sinar$\mathrm{X}$, ketidakseimbangan nutrisi, dan endokrin.

Pengaruh pengencer terhadap longivitas dan Recovery Rate (RR) Semen beku pasca Thawing

Menurut Garner dan Hafez (2000), semen yang dibekukan akan mengalami kerusakan sekitar $40 \%$. Kerusakan sel selama proses pembekuan dan thawing disebabkan karena terjadinya peroksidasi lipid pada spermatozoa sehingga dapat menurunkan daya hidup (Alvarez dan Storey, 1982). Kerusakan pertama pada membran sel spermatozoa terjadi pada proses pembekuan dan thawing antara suhu - 15 sampai $-60^{\circ} \mathrm{C}$ tetapi tidak terjadi selama penyimpanan di nitrogen cair (Park dan Graham, 1993). Pendinginan dan pemanasan kembali akan merusak lipoprotein yang ada pada membran sperma. Persentase sperma motil pasca thawing minimal $30 \%$ untuk dapat diinseminasikan (Campbell et al., 2003). Jadi berdasarkan teori ini semen dengan semua jenis pengencer masih layak digunakan dalam IB. Hal ini terlihat pada Tabel 4 yang menunjukkan persentase sperma motil pasca thawing jam ke-0 rata-rata lebih dari $40 \%$.

Menurut Salisbury dan Vandemark (1985), longivitas akan diperpanjang bila dalam larutan pencuci spermatozoa ditambahkan phospholipid dalam bentuk lecithin kacang kedelai dan kuning telur. Jadi berdasarkan teori ini, pengencer KK, TS, dan TF sama-sama mampu memperpanjang longivitas sperma. Tetapi hasil dari analisis statistik, pengencer $\mathrm{KK}$ memiliki longivitas (6 jam) dan RR $(50,20 \%)$ sangat nyata lebih tinggi $(\mathrm{P}<0,01)$ daripada pengencer yang lain. Sedangkan pengencer TS dan TF tidak berbeda nyata $(P>0,05)$ (Tabel 3 dan 5). Hal ini menunjukkan bahwa pengencer yang berbeda bahan dasarnya akan mempengaruhi kemampuan sperma untuk kembali lagi dan bertahan hidup secara in vitro. Perbedaan ini bisa saja disebabkan oleh bahan pengencer KK yang mengandung lecithin kacang kedelai diperkirakan lebih mampu melindungi sperma dari pengaruh buruk permbekuan daripada kuning telur. Selain mengandung lecithin kacang kedelai, pengencer $\mathrm{KK}$ diduga mengandung komponen dan komposisi bahan yang lebih sesuai untuk semen beku sapi.

Kedua semen beku yang menggunakan pengencer TS dan TF memiliki RR dan longivitas lebih rendah daripada semen dengan pengencer $\mathrm{KK}$. Hal ini kemungkinan disebabkan oleh komposisinya berbeda dengan Pengencer $\mathrm{KK}$, kemungkinan lain karena kuning telur yang 
terkandung dalam pengencer tersebut. Menurut Moussa et al. (2002), substansi yang terdapat dalam kuning telur ada yang menghambat respirasi dan mengurangi persentase sperma motil. Berdasarkan teori ini terbukti bahwa semen dengan pengencer TS dan TF yang menggunakan kuning telur memiliki $R R$ lebih rendah dibandingkan dengan pengencer KK. Selanjutnya masih menurut Moussa et al. (2002), substansi yang dibutuhkan sperma dari kuning telur dalam proses pembekuan semen adalah Low Density Lipoprotein (LDL). Untuk mendapatkan LDL tersebut harus diultrasentrifugasi. Dalam penelitian ini, kuning telur yang digunakan adalah seluruh komponen kuning telur termasuk substansi high density lipoprotein (HDL) yang dapat menghambat respirasi dan motilitas spermatozoa. Pada pengencer TS dengan metode Masuda, meskipun terjadi pengendapan butiran-butiran kuning telur tetapi belum bisa dikatakan bahwa yang terdapat dalam pengencer TS hanya substansi LDL. Hal ini terbukti pada saat pengamatan masih banyak terlihat butiran-butiran molekul yang kasar dan diduga akan menghambat pergerakan spermatozoa secara progresif.

Longivitas dan $R R$ sperma pasca thawing pada pengencer TS dan TF tidak berbeda nyata $(\mathrm{P}>0,05)$. Hal ini diduga karena bahan dasar kuning telur dan buffer yang digunakan sama, yaitu tris, walaupun teknik pembuatan dan gulanya berbeda. Hasil penelitian Suwarso (1999) menunjukkan bahwa raffinosa merupakan jenis gula yang baik untuk semen beku kambing dibandingkan gula yang lain tetapi ternyata dari hasil penelitian ini tidak berlaku untuk semen beku sapi FH.

\section{Kesimpulan dan Saran}

Semen beku dengan pengencer komersil lecithin kacang kedelai (KK) memiliki recovery rate pasca thawing lebih tinggi serta memiliki Iongivitas pasca thawing lebih lama daripada jenis pengencer tris TS dan TF.

Pengencer TS dan TF memiliki kualitas yang sama dalam hal recovery rate dan longivitas.
Perlu dilakukan penelitian tentang pengaruh endapan kuning telur pada berbagai pengencer tris dan perlunya mencari jenis lecithin dari tumbuhan lain yang dapat menggantikan kacang kedelai karena Indonesia masih mengimpor.

Perlu dilakukan usaha sendiri (lokal) untuk membuat pengencer yang berbahan dasar lecithin kacang kedelai karena pengencer komersil tersebut impor dari Jerman, sedangkan pengencer TF (buatan lokal FKH IPB) bisa digunakan untuk menggantikan tris endapan (TS) yang selama ini sudah memasyarakat.

\section{Daftar Pustaka}

Alvarez J. G. and B. T. Storey. 1982. Spontaneous lipid per oxidation in rabbit epididymal spermatozoa, its effect on sperm motility. Biologi Reproduksi. 27:1102-1108.

Bearden H. J. and J. W. Fuquay. 1997. Semen collection. In: Applied Animal Reproduction. $4^{\text {th }}$ Ed. Missisippi State University. New Jersey. 147-157.

Campbell J. R., K. L. Campbell, and M. D. Kenealy. 2003. Artificial insemination. In: Anim. Sci. $4^{\text {th }}$ Ed. Mc Graw-Hill. New York.

Garner, D. L., E. and S. E. Hafez. 2000. Spermatozoa and seminal plasma. In: Reproduction in Farm Animals. $7^{\text {th }}$ Ed B Hafez/ESE Hafez. Lippincott Williams \& Wilkins. USA. 96-109.

Holm L. and Wishart G. J. 1998. The Effect of pH on the motility of spermatozoa from chicken, turkey and quail. Anim. Reprod., Vol. 54:45-54.

Moussa, M., V. Martinet, A. Trimeche, D. Tanturier, and M. Anton. 2002. Low density lipoprotein extracted from hen egg yolk by an easy method : cryoprotective effect on frozen-thawed bull semen. Theriogenology. 57:15911762.

Parks, J. E. and J. K. Graham. 1992. Effect of cryopreservation procedures on sperm membranes. Theriogenology. 38:209-222 
Partodihardjo, S. 1987. Ilmu Reproduksi Hewan. Mutiara Sumber Widya. Jakarta.

Paulenz, H. Soderquist, L. R. Perez-Pe, and K. A. Berg. 2002. Effect of different extenders and storage temperatures on sperm viability of liquid ram semen. Theriogenology.57:823-836.

Rouge M. 2003. Sperm Motility. http://arbl. cvmbs.colostate.edu/hbooks/pathphys/re prod/semeneval/motility, html.

Salisbury G. W. and N. L. Vandemark. 1985. Fisiologi dan Reproduksi Inseminasi Buatan pada Sapi. Penerjemah R Djanuar. Gadjah Mada University Press. Yogyakarta.
Suwarso. 1999. Peranan raffinosa dalam pengencer tris-sitrat kuning telur terhadap semen beku kambing Peranakan Etawah [tesis]. Program Pascasarjana, Institut Pertanian Bogor. Bogor.

Tanari, M. 2001. Usaha Pengembangan Sapi Bali sebagai Ternak Lokal dalam Menunjang Pemenuhan Kebutuhan Protein asal Hewani di Indonesia, http://rudycit.250x.com/sem 1-012/mtanari.htm.

Webb, D. W. 2004. Artificial Insemination in Dairy Cattle. http://edis.ifas.ufl.edu/ BODYDSO 89\#table-1. 